\title{
Techno-Economic Study for Hybrid Renewable Energy System for Coastal Residential Application in Pekan, Pahang
}

\author{
${ }^{1 *}$ Roziah Zailan, ${ }^{2}$ Siti Nurzalikha Zaini, ${ }^{2}$ Muhammad Ikram Mohd Rashid, ${ }^{1}$ A.A. Razak \\ ${ }^{I}$ Faculty of Engineering Technology, Universiti Malaysia Pahang, Lebuhraya Tun \\ Razak, 26300, Kuantan Pahang. \\ ${ }^{2}$ Faculty of Electrical \& Electronics Engineering, Universiti Malaysia Pahang, \\ 26600 Pekan, Pahang Darul Makmur \\ *Email: roziahz@ump.edu.my
}

\begin{abstract}
Techno-economic study is needful to optimize the usage of renewable energy components that targeting low cost of electricity generation system. The selected case study area is coastal area in Pekan, Pahang, Malaysia. The autonomous system designed in this study is hybrid standalone PV-wind-diesel energy system to fulfil a $20.1 \mathrm{kWh} /$ day demand for a coastal housing. Such power system was designed and optimized further to meet the power demand at a minimum cost of energy using energy optimization software, Hybrid Optimization Model for Electric Renewables (HOMER). The analysis was focused on the operational characteristics, economics and environmental. The standalone PV-wind-diesel energy system has total net present cost about $\$ 61,911$ with cost of energy $\$ 0.66 / \mathrm{kWh}$. Apparently, the generation of electricity from both wind turbine and PV was inflated with the diesel generator system. From the payback period calculation, time taken to recover full capital invested through the installation of hybrid PV-wind-diesel is six years. Moreover, the installation of diesel generator should be optimizing in order to mitigate the environmental emissions
\end{abstract}

Indexed Terms- techno-economic study, Hybrid standalone PV-wind-diesel energy system, energy optimization software, payback period, environmental emissions.

\section{INTRODUCTION}

An abundant resources of solar and wind could be exploited to power up the coastal housing. However, the selection of location for suitable wind turbine and solar energy harvesting need to be studied in respect to the technology options, component costs, and resource availability. The study area located in Pekan, situated on the banks of Pahang River 50km South of Kuantan and near to popular beaches such as Legenda Beach and Air Leleh Beach. In this area, potential benefit to receive strongest wind and solar at coastal area will give advantages for this project. Therefore, this paper presents a feasibility study of hybrid standalone PV-wind-diesel energy system for Pekan, Kuantan Pahang. The analysis was done based on typical house power demand at about $20.1 \mathrm{kWh} /$ day and $1.23 \mathrm{~kW}$ peak demand [1]. Noted that all cost conversion in this study is $1 \$=\mathrm{RM} 4.28$ as of current rate (August 2017).

Generally, total cost for establishing such generating unit in new location with unknown harvesting energy units is unclear without proper techno economic study. Therefore, this study is beneficial to optimize the usage of renewable energy components that targeting low cost of energy production. The arrangement of wind turbine, solar panel, diesel generator and storage systems were considered. Several configurations in the simulation include size of components, capacity, lifetime and so forth. The National Renewable Energy Laboratory's (NREL) optimization tool "HOMER" was utilized to identify feasible hybrid configurations and their applicability. HOMER simulates the operation of a system by making energy balance calculations and displaying a list of configurations, sorted by net cost that can be used to compare 
system design [2].

In this study, the system was simulated to estimate its operational characteristics such as annual electricity production, annual loads served, excess electricity and capacity shortage. The proposed hybrid standalone PV-wind-diesel energy systems was compared concerning on their operational characteristics and cost value in order to meet the existing user's power demand at a minimum cost of energy.

There are various previous studies using HOMER to initiate hybrid power system in the coastal areas. Sadrul Islam et al. [3] was attempted to model a hybrid electricity generation system for a small community of the St Martin's Island in Bangladesh that resulted lowest COE $\$ 0.345 / \mathrm{kWh}$ and total net present cost (NPC) of $\$ 137,927$ with a renewable fraction of $31 \%$. A study in the same study area by Hazra et al. [4] also stated that the depending on diesel only is not feasible but to integrate it with hybrid energy generation system. They concluded that PVdiesel-wind-battery hybrid generation system was found most feasible and optimized. Nevertheless, Ibrahim et al. [1] stressed that the hybrid renewable energy system is suitable to be applied in the coastal areas if current costs of the renewable energy components could be marked down.

In Malaysia, FIT is a policy mechanism which allows users to sell back the additional electricity generated from PV system to Tenaga National Berhad (TNB) based on TNB rate. This study also attempted to look into the possibility to participate in the FIT program. For this reason, the payback period ROI were calculated for both FIT program and self-sustained house to identify which one is more reliable to be applied. Matin et al. [5] also calculated payback period of the proposed system using different tariff based on their country, Bangladesh after they simulated hybrid PV-wind-diesel power system in HOMER to determine number of years required to recover the cost of investment. Therefore the economic analysis section will discuss more on the paybacks period and ROI analysis between self-sustained house and FIT program.

\section{MATERIAL AND METHODS}

Electrical load: The electrical loads for the house are classified as domestic with basics electrical load components like fluorescent lamps, ceiling fan, television, refrigerator and also washing machine $[1,4]$. The hourly load consumed by the house is presented in Figure 1. Electricity demand is the rate at which electric energy is required by the load, measured in kilowatts $(\mathrm{kW})$ [6]. Average power demand was estimated at about $20.1 \mathrm{kWh} /$ day and peak demand of $1.23 \mathrm{~kW}$.

\section{Daily Profile}

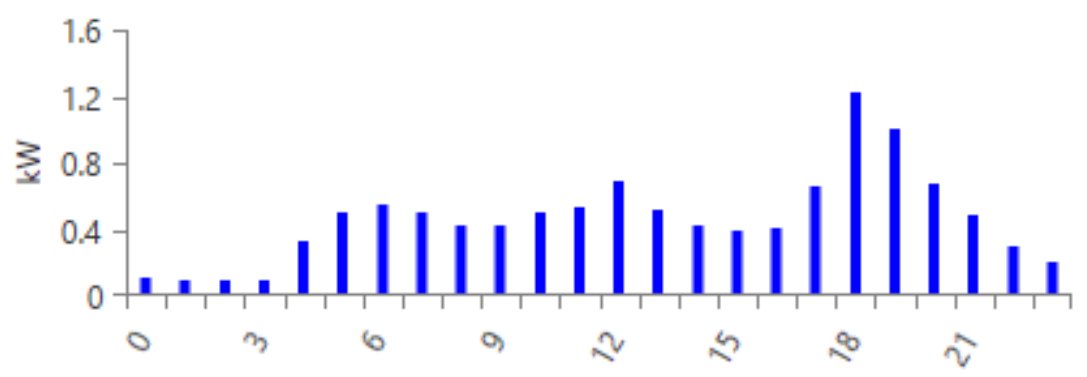

Figure 1: Hourly load consumption for typical house in coastal area 
Data Collection: There are two weather station located at a) Sek Men Ahmad Pekan between latitude $3^{\circ} 29^{\prime} 10^{\prime \prime} \mathrm{N}$ and longitude $103^{\circ} 23^{\prime} 34^{\prime \prime} \mathrm{E}$ with elevation of $4 \mathrm{~m}$ high off the ground which represents the coastal city, b) Kuantan between latitude $3^{\circ} 46^{\prime} 20^{\prime \prime} \mathrm{N}$ and longitude $103^{\circ} 12^{\prime} 43^{\prime \prime} \mathrm{E}$ with elevation of $15.23 \mathrm{~m}$ high off the ground which represent inland city.

Solar radiation resources: Hourly solar radiation data for year 2014 as in Figure 2 depicted monthly average solar radiation $(5.23 \mathrm{kWh} / \mathrm{m} / \mathrm{d})$ and clearness index. HOMER calculated clearness index (a measure of the clearness or cloudiness of the atmosphere) from latitude information and solar radiation of the site under investigation.

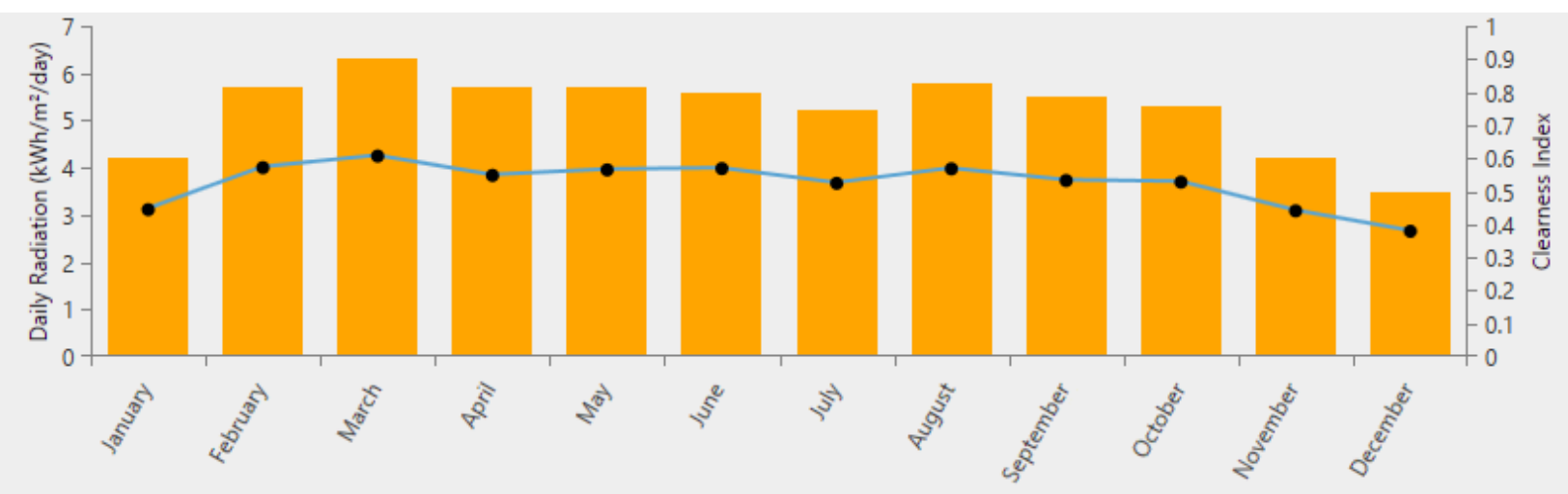

Figure 2: Monthly Average Daily Radiation and Clearness Index

Wind resources: Monthly wind speed data for year 2014 in Figure 3 also was collected from MMD and from this data the monthly average wind speed obtained is $1.76 \mathrm{~m} / \mathrm{s}$. The wind speeds are lower in April to Octoberr than the annual average wind speed while higher wind speeds were captured during the monsoon months (November-March).

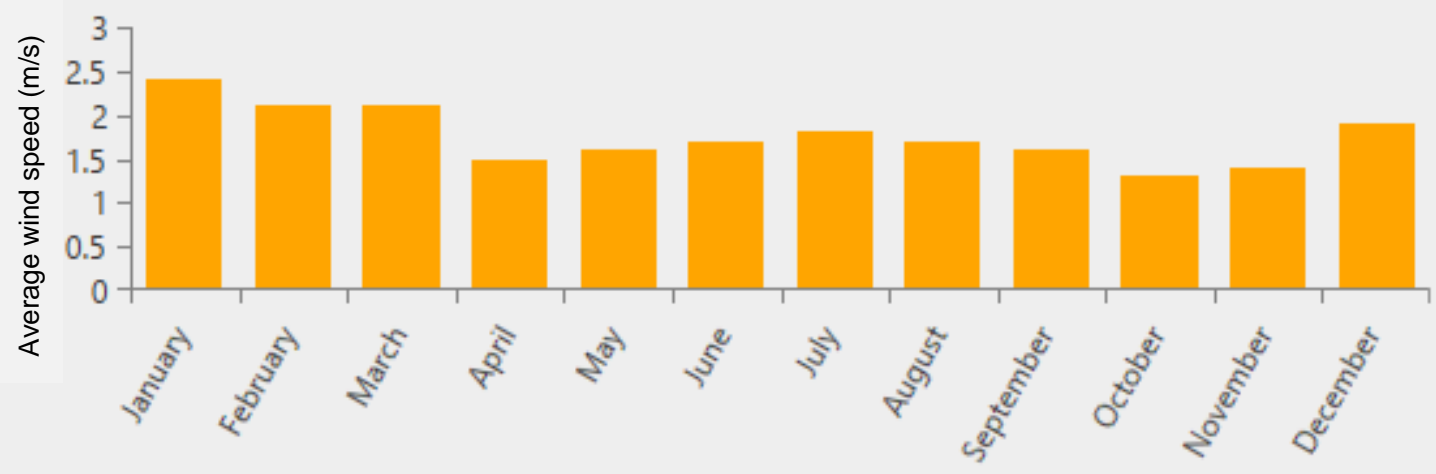

Figure : 3 Mean Surface Wind Speed

PV-wind-diesel power system: The schematic diagram of Photovoltaic (PV)-wind-diesel power system components are presented in Figure 4. The energy system consists of diesel generator, PV arrays, wind turbine, battery and power converters. Technical information like cost, quantity, capacity, operating hours and other specifications are needed to run the simulation using HOMER software. 
The details of the system components were obtained from manufacturers of the equipment and previous studies [6-11] The descriptions of these components are given below.

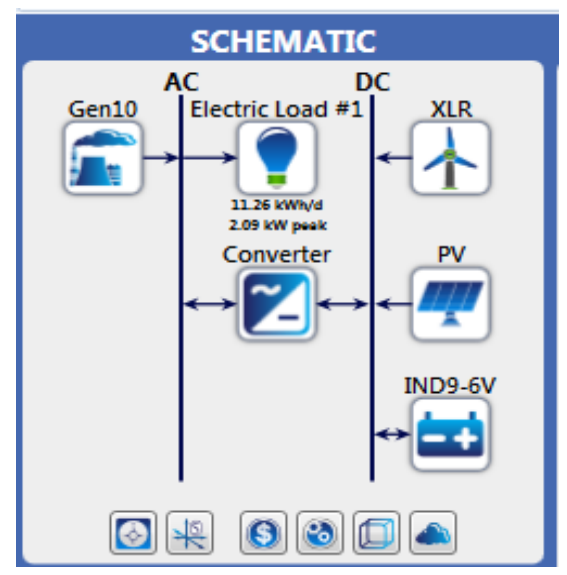

Figure 4 : PV-Wind-Diesel Power System Configuration

Table 1 : Cost of Components

\begin{tabular}{lllll}
\hline Equipment & $\begin{array}{l}\text { Capacity } \\
\text { /Unit }\end{array}$ & $\begin{array}{l}\text { Capital } \\
\text { Cost (\$) }\end{array}$ & $\begin{array}{l}\text { Replacement } \\
\text { Cost (\$) }\end{array}$ & O\&M Cost (\$) \\
\hline Diesel Generator & $16 \mathrm{~kW}$ & 6500 & 5800 & $0.15 / \mathrm{h}$ \\
Solar PV & $5 \mathrm{~kW}$ & 11000 & 9500 & - \\
Wind Turbine & $1 \mathrm{Unit}$ & 19400 & 15000 & $75 /$ year \\
$\begin{array}{l}\text { Batteries (Trojan } \\
\text { IND9-6V) }\end{array}$ & $1 \mathrm{Unit}$ & 1325 & 1190 & $0.02 / \mathrm{h}$ \\
\begin{tabular}{l} 
Converter \\
\hline
\end{tabular} & $1 \mathrm{~kW}$ & 118 & 100 & $15 /$ year \\
\hline
\end{tabular}

Diesel generator: The $16 \mathrm{~kW}$ diesel generator at cost $\$ 6500$ was being used as the peak power demand is less than $5 \mathrm{~kW}$. Replacement and operational costs are assumed to be $\$ 5800$ and $\$ 0.150 / \mathrm{h}$, respectively. The lifetime of diesel generator is $15000 \mathrm{~h}$. In this study no diesel generator $(0 \mathrm{~kW})$ or a 5 $\mathrm{kW}$ unit were used for simulation by HOMER.

PV-array: The installation cost of PV arrays may vary from $\$ 6.00-\$ 10.00 / \mathrm{W}$. A $1 \mathrm{~kW}$ solar energy system installation and replacement costs are taken as $\$ 11000$ and $\$ 9500$, respectively. Various sizes were considered, ranges from $0-6 \mathrm{~kW}$ in this study. The lifetime of the PV arrays are taken as 20 years and no tracking system was included in the PV system.

Wind turbine: Availability of energy from the wind turbine depends greatly on wind variations. Therefore, wind turbine rating is generally much higher compared to the average electrical load. In this analysis, Bergey wind power's BWC Excel-R model was considered. It has a rated capacity of 8.1 $\mathrm{kW}$ and provides $48 \mathrm{~V}$ DC as output. Cost of one unit was considered to be $\$ 19,400$ while replacement and O\&M costs were taken as $\$ 15,000$ and $\$ 75 /$ year respectively [11]. To allow the simulation program to hit an optimum solution, provision for using several units $(0,12,24,26,28,30$ and 32) were considered for the study location. The lifetime of the turbine was taken as 20 years.

Batteries: Batteries are considered as a major cost factor in small-scale stand-alone power systems. A battery bank of commercially available units, Trojan IND9-6V model (6 V, 1156 Ah and $9645 \mathrm{~kW}$ ) [7] was considered in this simulation. The estimated lifetime is 5 years and the cost of one 
battery is $\$ 1325$ with a replacement cost of $\$ 1190$ while the O\&M cost is $\$ 0.02 / y r$ were considered for this study. The battery stacks may contain a number of batteries range from $0-125$ units.

Power converter: A power electronic converter needs to maintain flow of energy between the AC and DC components. For a $1 \mathrm{~kW}$ system the installation and replacement costs were taken as $\$ 118$ and $\$ 100$, respectively. Four different sizes of converters $(0,2,5$ and $7 \mathrm{~kW})$ were considered for the simulation. Lifetime of a unit was considered to be 15 years with an efficiency of $90 \%$.

\section{RESULT AND DISCUSSION}

\subsection{PV-Wind-Diesel System Analysis}

PV-wind-diesel system simulation: For hybrid PV-wind- diesel energy system, the equipment needed to build the system were diesel generator, PV array, wind turbine, batteries and power electronic converter with specified type and quantity. The HOMER simulation tool was used to optimize the sizes of different hardware components in the PV-wind-diesel system, taking into account the technical characteristics of system operation and minimizing total net present cost of the system.

HOMER evaluated operational characteristics, annual cost and net present cost for main component, annual electrical energy production, annual load served, excess electricity, renewable energy fraction, capacity shortage and unmet load. The optimization results of this power system are show in Figure 5.

\begin{tabular}{|c|c|c|c|c|c|c|c|c|c|c|c|c|c|c|c|c|}
\hline \multicolumn{12}{|c|}{ Architecture } & \multicolumn{4}{|c|}{ Cost } & \multirow{2}{*}{$\begin{array}{c}\text { System } \\
\text { Ren Frac } \checkmark \\
(\%)\end{array}$} \\
\hline \multirow[t]{7}{*}{$\triangle$} & 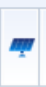 & 个 & E & $\Rightarrow$ & $\boldsymbol{z}$ & $\underset{(\mathrm{kW})}{\mathrm{PV}} \nabla$ & XLR $\checkmark$ & $\underset{(k W)}{D G} \nabla$ & S6CS25P $\checkmark$ & $\begin{array}{c}\text { Converter } \\
(\mathrm{kW})\end{array}$ & Dispatch $\checkmark$ & ${ }_{(\$)}^{\mathrm{COE}} \nabla$ & $\begin{array}{c}\mathrm{NPC} \\
(\$)\end{array}$ & $\begin{array}{l}\text { Operating } \\
\text { cost } \\
(\$)\end{array}$ & $\begin{array}{c}\text { Initial capital } \\
(\$)\end{array}$ & \\
\hline & & & E & $=0$ & $\boldsymbol{z}$ & & & 5.00 & 6 & 2.00 & $\mathrm{CC}$ & $\$ 0.584$ & $\$ 54,508$ & $\$ 3,585$ & $\$ 8,686$ & 0.0 \\
\hline & $m$ & & E & $=4$ & z & 0.250 & & 5.00 & 6 & 2.00 & $\mathrm{CC}$ & $\$ 0.587$ & $\$ 54,800$ & $\$ 3,564$ & $\$ 9,236$ & 0.0 \\
\hline & & r & E & $\rightarrow$ & $\approx$ & & 1 & 5.00 & 6 & 5.00 & $\mathrm{CC}$ & $\$ 0.659$ & $\$ 61,496$ & $\$ 2,586$ & $\$ 28,440$ & 22 \\
\hline & $m$ & r & $E$ & $\Leftrightarrow$ & $\boldsymbol{z}$ & 0.250 & 1 & 5.00 & 6 & 5.00 & $\mathrm{CC}$ & $\$ 0.663$ & $\$ 61,911$ & $\$ 2,575$ & $\$ 28,990$ & 23 \\
\hline & & & E & & & & & 5.00 & & & $\mathrm{CC}$ & $\$ 0.787$ & $\$ 73,404$ & $\$ 5,703$ & $\$ 500.00$ & 0.0 \\
\hline & $m$ & & E & & $\approx$ & 0.250 & & 5.00 & & 2.00 & $C C$ & $\$ 0.800$ & $\$ 74,660$ & $\$ 5,740$ & $\$ 1,286$ & 0.0 \\
\hline$\triangle$ & & r & $E$ & & $\boldsymbol{z}$ & & 1 & 5.00 & & 2.00 & $\mathrm{CC}$ & $\$ 0.971$ & $\$ 90,571$ & $\$ 5,510$ & $\$ 20,136$ & 0.0 \\
\hline \multirow[t]{2}{*}{$\Delta$} & 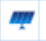 & r & E & & $\tilde{z}$ & 0.250 & 1 & 5.00 & & 2.00 & $\mathrm{CC}$ & $\$ 0.975$ & $\$ 91,007$ & $\$ 5,501$ & $\$ 20,686$ & 0.0 \\
\hline & & 小 & & $=1$ & $\tilde{z}$ & & 24 & & 36 & 5.00 & $\mathrm{CC}$ & $\$ 6.54$ & $\$ 609,997$ & $\$ 7,518$ & $\$ 513,890$ & 100 \\
\hline
\end{tabular}

Figure 5 : The Simulation Results For PV-Wind-Diesel Energy System

The least Cost of Energy (COE), $\$ 0.58 \mathrm{~kW} / \mathrm{h}$ resulted from the $5 \mathrm{~kW}$ diesel generator alone without contribution from renewable sources. But the integration with renewable energies fell into fourth least COE as $\$ 0.66 \mathrm{~kW} / \mathrm{h}$, resulted from the combination of $5 \mathrm{~kW}$ diesel generator, $0.25 \mathrm{~kW}$ of PV array, 1 unit of wind turbine, 6 unit of batteries and $5 \mathrm{~kW}$ converter. The strategy taken in this simulation is to ensure the power generator provide enough power to meet the demand. The renewable energy sources in collaboration with the diesel generator were evaluated to determine the feasibility of the system.

All values related to the electricity production and load served by the system are summarized in Table 2. The results of the simulation showed that the PV-wind-diesel hybrid system had a total annual electrical energy production of $10,046 \mathrm{kWh} / \mathrm{yr}$. The electricity generation came mostly from diesel generator with $56.32 \%$ at about $5,658 \mathrm{kWh} / \mathrm{yr}$ while wind turbine and $\mathrm{PV}$-array generated energy at $42.82 \%(4,301 \mathrm{kWh} / \mathrm{yr})$ and $0.87 \%(87 \mathrm{kWh} / \mathrm{yr})$, respectively. Besides that, it is clear that 
approximately $8.7 \%$ of energy $(873.5 \mathrm{kWh} / \mathrm{yr})$ was neglected. Several amount of excess energy can be suggested to cater for PV-wind hydrogen energy system in the next study. The trend of monthly electricity production can be referred to Figure 6.

Table 2 : Operational Characteristics of the PV-Wind-Diesel System

\begin{tabular}{lll}
\hline Annual Electricity Production & $\mathrm{kWh} / \mathrm{year}$ & $\%$ \\
\hline PV-array & 87 & 0.87 \\
Diesel generator & 5,658 & 56.32 \\
Wind Turbine & 4,301 & 42.82 \\
Total production & $\mathbf{1 0 , 0 4 6}$ & $\mathbf{1 0 0 . 0 0}$ \\
Annual electrical load served & & \\
AC primary load served & 7,300 & 100 \\
Total & 7,300 & 100 \\
Other & & \\
Excess electricity & 873.5 & 8.7 \\
Unmet electric load & 0.0 & 0.0 \\
Capacity shortage & 0.0 & 0.0 \\
Renewable fraction & 100 & \\
Capacity factor (PV) & & 3.99 \\
Capacity factor (Wind turbine) & & 6 \\
\hline
\end{tabular}

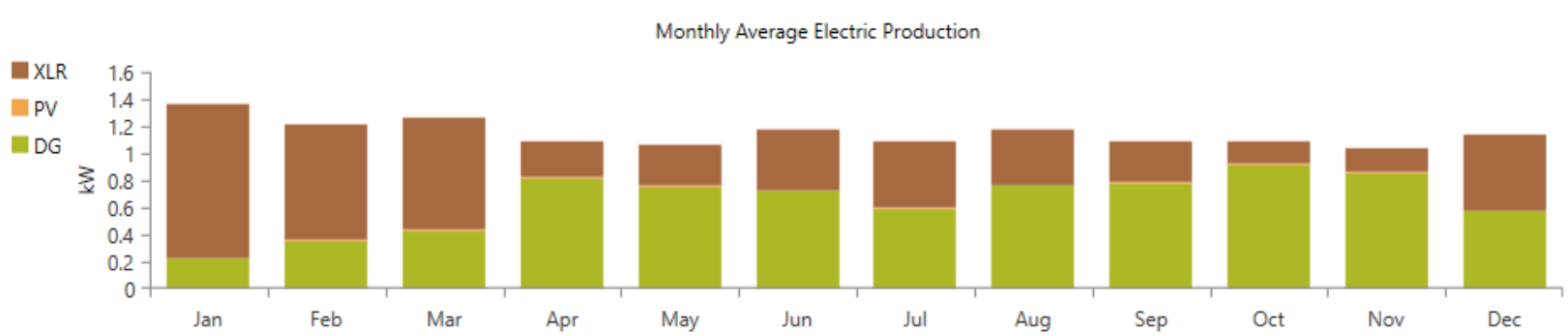

Figure 6 : Monthly Electricity Production Trend of The PV-Wind-Diesel System

From figure 7, it can be concluded that the most expensive annualized cost is from wind turbine at $\$ 1,518$ followed by batteries (\$622), converter (\$46), PV (\$43) and diesel generator (\$39). Total annualized cost for overall system is $\$ 4,843$. Table 3 provides complete breakdown of annualized cost.

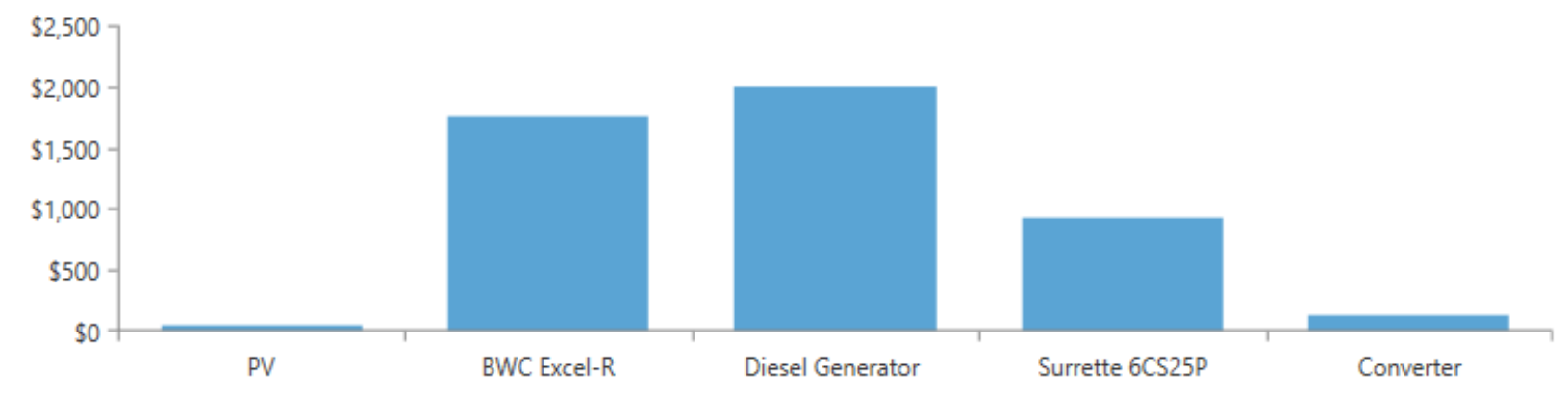

Figure 7 : Annualized Cost for Main Components Of The PV-Wind-Diesel System 
Table 3 : Breakdown of Annualized Cost

\begin{tabular}{lllllll}
\hline Component & Capital & Replacement & O\&M & Fuel & Salvage & Total \\
\hline PV & 43 & 12 & 0 & 0 & -6 & 48 \\
BWC Excel-R & 1,518 & 366 & 75 & 0 & -205 & 1,753 \\
Diesel Generator & 39 & 62 & 0 & 1,904 & -8 & 1,997 \\
Surrette 6CS25P & 622 & 416 & 0 & 0 & -119 & 918 \\
Converter & 46 & 12 & 75 & 0 & -7 & 127 \\
System & 2,268 & 867 & 150 & 1,904 & -346 & 4,843 \\
\hline
\end{tabular}

HOMER uses the total net present cost (NPC) to represent the life-cycle cost of a system (Figure 8). The highest NPC came out from the BWC Excel-R wind turbine $\$ 19,400$, followed by batteries $\$ 7,950$, converter $\$ 590$, PV panel $\$ 550$ and diesel generator $\$ 500$. Total NPC is $\$ 61,911$. On top of that, the breakdown of each device and cost summary about capital, fuel, operating, replacement and salvage can be seen in Table 4 .

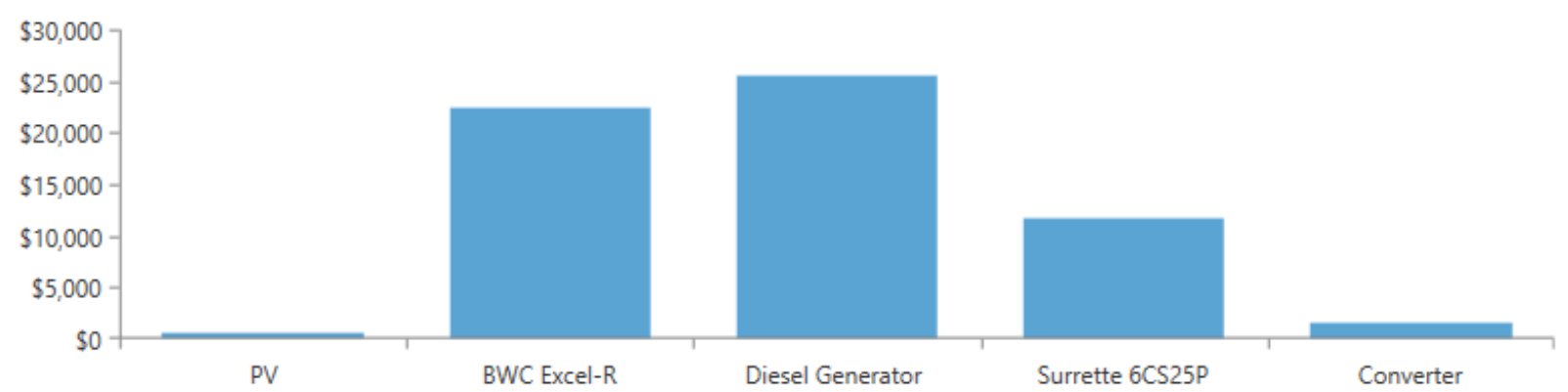

Figure 8 : Net Present Cost For Main Components Of The Pv-Wind-Diesel System

Table 4 : Breakdown of Net Present Cost (NPC)

\begin{tabular}{lllllll}
\hline Component & Capital & Replacement & O\&M & Fuel & Salvage & Total \\
\hline PV & 550 & 148 & 0 & 0 & -83 & 615 \\
BWC Excel-R & 19,400 & 4,677 & 959 & 0 & $-2,621$ & 22,415 \\
Diesel Generator & 500 & 789 & 0 & 24,339 & -102 & 25,526 \\
Surrette 6CS25P & 7,950 & 5,312 & 2 & 0 & $-1,525$ & 11,738 \\
Converter & 590 & 156 & 959 & 0 & -87 & 1,617 \\
System & 28,990 & 11,082 & 1,919 & 24,339 & $-4,419$ & 61,911 \\
\hline
\end{tabular}

From this study, diesel generator apparently contributed highest portion of electricity while wind speed is highly potential in three months, January, February and March. The contribution from solar is very minimal. However, fully dependent on the consumption of diesel fuel can be reduced with involvement of renewable resources. All in all, capital cost, total Net Present Value (NPC) and COE of the systems were recorded as $\$ 28,990, \$ 61,911$ and $\$ 0.66 / \mathrm{kWh}$ respectively.

\subsection{Comparison Homer Coe with TNB Tariff}

Economic analysis was done to compare HOMER with TNB tariff. Table 5 presented detail breakdown of both HOMER and TNB calculation for annual energy consumption of the proposed house. Annual electricity consumption was estimated at $7300 \mathrm{kWh} / \mathrm{yr}$ at cost $\$ 4818 / \mathrm{yr}$ based on HOMER and \$576/yr for TNB. Apparently, cost of electricity consumption is higher if the house solely depending on the TNB grid system. 
However, payback period was calculated to identify specific duration to recover the cost of investment of the system. From the payback period calculation was done for the HOMER analysis, time taken to recover full capital invested through the installation of hybrid PV-wind-diesel is six years. Thus, after six years the owner will gain profit as a self-sustained house.

Table 5 : Comparison between Self-Sustained House and FIT Program

\begin{tabular}{|c|c|}
\hline HOMER COE $(\$ 0.66 / \mathrm{kWh})$ & TNB TARIFF (\$0.21/kWh) \\
\hline Total capital cost $=\$ 28,990$ & Total capital cost $=\$ 28,990$ \\
\hline $\begin{array}{l}\text { Annualize income }=\text { Total usage } \times \text { HOMER COE } \\
=7,300 \mathrm{kWh} / \mathrm{yr} \times \$ 0.66 / \mathrm{kWh} \\
=\$ 4818 / \mathrm{yr}\end{array}$ & $\begin{array}{l}\text { Annualize income }=\text { Total production } \mathrm{x} \text { TNB tariff rate } \\
(\$)\end{array}$ \\
\hline $\begin{array}{l}\text { Payback period }=\text { Total capital cost } / \text { annualize } \\
\text { saving } \\
=\$ 28,990 / \$ 4818 / \mathrm{yr} \\
=6 \text { years }\end{array}$ & $\begin{array}{l}\text { For the first } 200 \mathrm{kWh}: 1-200 \mathrm{kWh} / \text { month }=\$ 0.05 / \mathrm{kWh} \\
\text { For the next } 100 \mathrm{kWh}: 201-300 \mathrm{kWh} / \mathrm{month}= \\
\$ 0.07 / \mathrm{kWh} \\
\text { For the next } 300 \mathrm{kWh}: 301-600 \mathrm{kWh} / \mathrm{month}= \\
\$ 0.12 \mathrm{sen} / \mathrm{kWh}\end{array}$ \\
\hline & $\begin{array}{l}\text { Thus, } 20.1 \mathrm{kWh} \times 30 \text { days }=603 \mathrm{kWh} \\
\begin{aligned} \text { Electricity bill }=\$ 48 / \text { month } \\
=\$ 576 / \text { year }\end{aligned}\end{array}$ \\
\hline
\end{tabular}

\subsection{Environmental Analysis}

Total emissions resulting from the proposed system are shown in Table 6 which is definitely emitted from the operation of diesel generator. $5 \mathrm{~kW}$ Diesel generator was integrated in this system as wind and solar resources are variable energy sources that depending on the weather conditions. Electricity generation cannot be expected to be generated totally from those renewable resources [12]. It was proven from the results where the electricity generation derived mostly from diesel generator with $56.32 \%$ at about $5,658 \mathrm{kWh} / \mathrm{yr}$ while wind turbine and PV-array generated energy at $42.82 \%$ $(4,301 \mathrm{kWh} / \mathrm{yr})$ and $0.87 \%(87 \mathrm{kWh} / \mathrm{yr})$, respectively. Both wind and solar resources are not strong enough to fulfil the power requirement. Various emissions of pollutants were emitted as a result of fuel consumption of $5 \mathrm{~kW}$ of diesel generator at about $2380 \mathrm{~L}$. From the emission analysis, significant amount of pollutants were carbon dioxide about $6267 \mathrm{~kg} / \mathrm{yr}$ and nitrogen oxides $138 \mathrm{~kg} / \mathrm{yr}$. Both pollutants are considered as greenhouse gases (GHG) that contributed substantially to climate change as the GHG trapped in the atmosphere [13]. For this reason, further study is needed to optimize the use of diesel generator in order to mitigate the environmental impacts from the emission.

Table 6 : Total Emissions from PV-Wind-Diesel System

\begin{tabular}{ll}
\hline Pollutant & Emissions $\mathbf{( k g / y r )}$ \\
\hline Carbon dioxide & 6267 \\
Carbon monoxide & 15 \\
Unburned hydrocarbons & 2 \\
Particulate matter & 1 \\
Sulfur dioxide & 13 \\
Nitrogen oxides & 138 \\
\hline
\end{tabular}

\section{CONCLUSION}

At the end of HOMER simulation, standalone PV-wind-diesel energy system presented total net present cost about $\$ 61,911$ that capable to generate electricity at cost of energy $\$ 0.66 / \mathrm{kWh}$. From the economic analysis, it has resulted that it will take about six years to recover full capital invested 
through the installation of hybrid PV-wind-diesel. This study may be extended to involve the integration of other renewable resources system for an extensive coastal area in the future. Further study is also needed to optimize the use of diesel generator in order to mitigate the environmental emissions.

\section{ACKNOWLEDGMENTS}

The acknowledgement goes to Universiti Malaysia Pahang for providing financial support through UMP Research Grant scheme vote no RDU14036.

\section{REFERENCES}

[1] M. Z. Ibrahim, R. Zailan, M. Ismail and A. M. Muzathik, Pre-Feasibility Study of Hybrid Hydrogen Based Energy Systems for Coastal Residential Application, Energy Research Journal. 2010, 1 (1):12-21.

[2] Areef Kassam, HOMER Software Training Guide for Renewable Energy Base Station Design. 2010.

[3] A. K. M. Sadrul Islam, M. M. Rahman, M. A. H Mondal and F. Alam, Hybrid energy system for St. Martin island, Bangladesh: An optimized model, Procedia Engineering. 2012, 49: 179-188.

[4] S. R Hazra, K. S. Hossain, A. Al Jubaer and M. Rabby, An Optimized Hybrid System Model: Solution for Coastal Area in Bangladesh, International Journal of Research in Engineering and Technology. 2014, 3 (12): 94-102.

[5] M. A Matin, \& A. Deb, Optimum Planning of Hybrid Energy System using HOMER for Rural Electrification. 2013, 66(13): 45-52.

[6] A. Demiroren and U. Yilmaz, Analysis of change in electric energy cost with using renewable energy sources in Gokceada, Turkey: An island example. Renewable and Sustainable Energy. 2014, 14: 323-333.

[7] M.J. Khan and M.T. Iqbal, Pre-feasibility Study of Stand-alone Hybrid Energy Systems for Applications in Newfoundland. Renewable Energy. 2005, 30: 835-854.

[8] E.I. Zoulias and N. Lymberopoulos, Techno- Economic Analysis of the Integration of Hydrogen Energy Technologies in Renewable Energy-Based Stand Alone Power Systems. Renewable. Energy, 2007, 32: 680696.

[9] W.C Goh and N.N. Barsoum, Balancing Cost, Operation and Performance in Integrated Hydrogen Hybrid Energy System, 2006. http://www.itee.uq.edu.au/ aupec/aupec06/htdocs/ content/pdf/3.pdf

[10] G.J. Dalton, D.A. Lockington and T.E. J. Baldock, Feasibility Analysis of Renewable Energy Supply Options for a Grid-Connected Large Hotel. Renewable Energy, 2009. 34: 955-964.

[11] Bergey Wind Power. Small wind turbines: For homes, business and off-grid. 2017. http://www.bergey.com.

[12] Enache (Firincă) Sanda Diana, Mircea Paul Mihai, Simulation of a Distributed Generation System Using Specialized Programs, Proceeding of the Optimization of Electrical and Electronic Equipment (OPTIM), 2014 International Conference, 22-24 May 2014

[13] Environmental Protection Agency. 2017. https://www.epa.gov. 